\title{
Mitigation of Petroleum Pollution: A Mini Review
}

\author{
Harendra K Sharma* and Manoharmayum Vishwanath Sharma \\ Jiwaji University, India
}

Submission: September 18, 2017; Published: September 22, 2017

*Corresponding author: Harendra K Sharma, School of Studies in Environmental Science (IGAEERE), Jiwaji University, India, Email: drhksharmagwl@gmail.com

Abstract

The pollution due to petroleum is a major concern. The hydrocarbon contaminant can have different adverse effects on the biotic community at the site of contamination. The dynamic of pollution due to oil spill is different for water and for land. Bioremediation as a mitigation measure is drawing attention and is a viable option for an eco-friendly approach for treatment of the petroleum based hydrocarbon contamination.

\section{Introduction}

The production of petroleum per year is over 2 billion metric tons and about $0.08-0.4 \%$ of this, is estimated to end up polluting the oceans. Considering the major production petroleum, refining and utilization is done on land, land pollution due to petroleum is a major concern. Over $90 \%$ of the total anthropogenic petroleum hydrocarbons (PHC) pollution in marine and terrestrial environment is a result of the low level routine discharge as effluents, urban runoffs, cleaning, oil treatment, etc,. The press coverage and public focus is on the production and transportation accidents, which accounts for only $5 \%$ to $10 \%$ of the total discharge, due to their drastic and high visibility [1].

The list of most hazardous xenobiotics includes aliphatic, ethylenic, cycloparaffin, or polycyclic aromatic hydrocarbons (PAH) which are of petroleum origin. PAHs are carcinogen, mutagenic and embryotoxic. The hydrocarbons are bound to be degraded when introduced to the environment however the degradation of PAH takes longer time as compared to aliphatic hydrocarbons which is rather rapid [2].

\section{Water and Soil Pollution of Petroleum}

The mechanism of oil spill varies depending on whether it is on land or in water. As water and oil cannot be mixed, oil tends to spread over a area on the surface of water. This is influenced to a great extent by the temperature of the water, wind, viscosity of the oil, etc,. In case of oils with light to medium consistency, in the first few days about $25 \%$ to $35 \%$ may be lost due to the volatility of the oil and photo degradation. In soil the dynamics is quite different; there is a rapid vertical infiltration in soil which can be countered by freezing or saturatuin by water. The photo degradative and evaporative losses are comparatively much lesser in soil then in water and is only about $1 \%-2 \%$ of the quantity of the spill. In aquatic systems, the dissolution of the polar PHCs gradually takes place. The results of photo oxidation and biodegradation are long chain fatty acids and others with surfactant properties. The turbulences in water in marine environment and the presence of these compounds results in the dispersion of the oil slick over time. Here two circumstances can be seen. First, the facilitation of the biodegradation with the incrase in the surface area of the oil in water emulsions though this minimizes the losses due to evaporation and photo degradation. Second, production of water in oil emulsion (also known as chocolate mousse) due to incomplete dispersion of the slick leading to conditions unfavorable for the biodegradation. The mousse slowly weathers and forms a tarry residue. Tar is also formed from the refractory PHC components and products of condensation during the process of photo degradation and biodegradation. Tar is difficult to biodegrade. PHCs in the form of slick or mousse that come ashore gets incorporated with the water or beach sediments. If the sediments are saturated with oil and water develops anoxic conditions which is unfavorable for biodegradation of PHCS. On terrestrial environment the factors responsible for the surface spreading of PHCs are numerous and complex and have a little mathematically predictive value. In an unsaturated soil, infiltration of soil is initially vertically down and then laterally over the soil water table. In the case of 
land, adsorption by soil particles contributes by minimizing the rate and distance of the movement of PHCs. The biodegradation of oil decreases as the depth increases due to lack of oxygen, complementary nutrients and viable microorganisms [1].

Petroleum products can hamper the biodiversity of soil and lead to unsuitable conditions in case of severe contamination. This can be checked by measuring the enzymatic activities. the population and the species of soil microorganism and soil enzyme (dehydrogenases, urease, phosphatases) activity are monitored for the chronic ecotoxicological studies [2].

\section{Mitigation}

\section{Soil}

Application of bioremediation has drawn significant attention as a secondary treatment alternative for oil removal since it was first used in Exxon Valdez spill in 1989. There are several methods of crude oil bioremediation like biostimulation, bioaugmentation, phytoremediation etc. In biostimulation, nutrient and other substrates which acts as the limiting factors are added to stimulate the growth of the indigenous oil degrading microorganisms. Bioaugmentation is the addition of other oil degrading microorganisms to aid the degradation of oil by the indigenous species. Phytoremediation is the degradation of the contamination by higher plants (eg. Vigna unguiculata) [3].

The addition of nutrients in the form of chemical fertilizer aids in the degradation of the petroleum by the indigenous microbial population and yields better result as compared to phytoremediation and addition of organic fertilizer in the form of poultry dung. The addition of inorganic fertilizer results in the highest hydrocarbon loss and increases the nutrient level to a higher level than phytoremediation. Phytoremediation can increase the nitrogen levels aiding in fulfilling the nitrogen required by the indigenous microbes for the degradation of the petroleum hydrocarbons if a leguminous plant due to the symbiotic association with Rhizobium is used. A decrease in the phosphate may occur due to the utilization by the plant for its growth and development [3].

\section{Water}

A slow increase in the population densities up to $90 \%$ of the total microbial community of the obligate hydrocarbonoclastic bacteria (OHCB) with the influx of oil in the marine environment. Alcanivorax, which are aliphatic hydrocarbon degraders, are the first to bloom followed by Cycloclasticus which degrade the remaining compounds. Similar results found from studies conducted with samples for oil contaminated site or uncontaminated sea water with added oil in the laboratory has confirmed the crucial role of the OHCBs in the degradation of oil hydrocarbons in marine waters. In the samples contaminated oil, tetrad cane or naphthalene was tested in the absence and presence of mineral nutrients. The initial community mainly composed of Arcobacter where domination by hydrocarbonoclastic bacteria was observed after the addition of hydrocarbons. In the OHCB bloom, Alcanivorax domination was reported in case of added with crude oil; in tetradecane added samples Thalassolituus dominance was reported; in naphthalene added samples Neptunomonas-like microbes dominated.

Similar results have been found by other researches as also. Samples from Thames salt marsh water collected from a near an oil refinery were spiked with crude oil and oil constituents. This showed blooms of Thalassolituus and Roseobacter. Alcanivorax and Cycloclasticus were seen in samples spiked with branched aliphatic hydrocarbon pristine and polydroxyalkanoate (PAH) respectively. Pseudomonas, Shewanella, Marinobacter, Psychrobacter and Pseudoalteromonas have been identified as in oil-degrading communities of Arctic sea ice [4].

Cyanobacterias also show ability to degrade oil. Oscillatoria salina showed Anthracene, Phenanthrene, Hexadecane degradation of $90.6 \%, 22.4 \%$ and $48.4 \%$ respectively. Plectonema terebrans showed Anthracene, Phenanthrene, Hexadecane degradation of $62.7 \%, 22.4 \%$ and 60.1\% respectively. Aphanocapsa sp. showed Anthracene, Phenanthrene, Hexadecane degradation of $41.9 \%, 85.5 \%$ and 65.2 respectively [5].

\section{Conclusion}

There is an increasing concern for the pollution caused from the use and petroleum accidents. Oil spills can be disastrous for the marine biodiversity at the site of the spill. There is also an increasing interest in the mitigation measures for the control of oil spills. Petroleum being natural and mainly of hydrocarbon several microorganisms on earth have the capability to break it down. These properties can be utilized for the cleanup of oil spills. Bioremediation methods can be adopted for a more ecofriendly approach to the control of oil spills and hydrocarbon degradation.

\section{References}

1. Bartha R (1986) Biotechnology of Petroleum Pollutant Biodegradation. Microbial Ecology 12(1): 155-172.

2. Wyszkowska J, Wyszkowski M (2010) Activity of Soil Dehydrogenases, Urease, and Acid and Alkaline Phosphatases in Soil Polluted with Petroleum. J Toxicol Environ Health A 73(17-18): 1202-1210.

3. Tanee FBG, Kinako PDS (2008) Comparative Studies of Biostimulation and Phytoremediation in the Mitigation of crude Oil Toxicity in Tropical Soil. J Appl Sci Environ Manage 12(2): 143-147.

4. Yakimov MM, Timmis KN, Golyshin PN (2007) Obligate oil-degrading marine bacteria. Curr Opin Biotechnol 18(3): 257-266.

5. Raghukumar C, Vipparty V, David JJ, Chandramohan D (2001) Degradation of crude oil by marine cyanobacteria. Appl Microbiol Biotechnol 57(3): 433-436. 
This work is licensed under Creative Commons Attribution 4.0 Licens DOI: 10.19080/RAPSCI.2017.03.555604

\section{Your next submission with Juniper Publishers will reach you the below assets}

- Quality Editorial service

- Swift Peer Review

- Reprints availability

- E-prints Service

- Manuscript Podcast for convenient understanding

- Global attainment for your research

- Manuscript accessibility in different formats ( Pdf, E-pub, Full Text, Audio)

- Unceasing customer service

Track the below URL for one-step submission https://juniperpublishers.com/online-submission.php 